\title{
PREDICTIVE MODELLING OF BURNOUT AMONG KAZAKHSTANI ENGLISH TEACHER CANDIDATES
}

\author{
B. A. Zhetpisbayeva1, A. Ye. Seilkhanova ${ }^{2}$, G. B. Sarzhanova ${ }^{3}$ \\ Buketov Karaganda University, Karaganda, Kazakhstan. \\ E-mail: ${ }^{1}$ zhetpisbajeva@mail.ru, ${ }^{2}$ seylkhanova.ksu@mail.ru; ${ }^{3}$ galiya008@mail.ru \\ E. Cem \\ Adam Mickiewicz University, Poznan, Poland. \\ E-mail: cemerdemm@gmail.com \\ B. R. Ospanova \\ Karaganda Technical University, Karaganda, Kazakhstan. \\ E-mail: o.b.r@mail.ru
}

\begin{abstract}
Introduction. In Kazakhstan, 55\% of English pre-service teacher candidates do not plan to work in public schools after graduation. The current quantitative study, using statistical analysis, sought to determine the causes of this phenomenon.

The aim of the present research was to determine the probability of early career burnout among future English teachers using predictive modeling.

Methodology and research methods. To create a predictive model, the authors used the following statistical data analysis tools: factor analysis, ordinal regression, and the Chi-square test. The selection of the above tools provides to predict the probability of work intention in a Kazakhstani public school for more than five years. This period acts as a proxy variable for predicting future teachers' burnout rates. The study involved 160 pre-service teachers, who received State scholarships for free tuition, with an obligation to work in public schools after graduation.

Results and scientific novelty. The data indicated that some respondents would only work for a period of less than five years, due to a sense of despair about their profession. The results demonstrate that pre-service teachers require better training. Furthermore, the authors found a correlation in teaching career expectations and the gender gap, where mature female participants were more likely to carry an intention to work for more than five years.

Practical significance. The present study makes a contribution to further research aimed at preventing the shortage and turnover of teaching staff in the workplace by detecting early warning signs of burnout among prospective teachers. The authors identified the indicators of the risk group of novice teachers, who are more prone to burnout due to emotional exhaustion, low self-efficacy, low expectations, and prospects from a teaching career. The authors believe that effective career guidance provides an adequate selection of the most motivated applicants with high occupational expectations.
\end{abstract}

Keywords: predictive modelling, student burnout, intention to work, English teacher candidates, early stage disappointment. 
For citation: Zhetpisbayeva B. A., Seilkhanova A. Ye., Sarzhanova G. B., Cem E., Ospanova B. R. Predictive modelling of burnout among Kazakhstani English teacher candidates. The Education and Science Journal. 2021; 23 (2): 71-93. DOI: 10.17853/1994-56392021-2-71-93

\title{
ПРОГНОСТИЧЕСКОЕ МОДЕЛИРОВАНИЕ ВЫГОРАНИЯ СРЕДИ БУДУЩИХ УЧИТЕЛЕЙ АНГЛИЙСКОГО ЯЗЫКА В КАЗАХСТАНE
}

\author{
Б. А. Жетписбаева ${ }^{1}$, А. Е. Сейлханова², Г. Б. Саржанова ${ }^{3}$ \\ Карагандинский университет им. Е. А. Букетова, Караганда, Казахстан.
} E-mail: ${ }^{1}$ zhetpisbajeva@mail.ru, ${ }^{2}$ seylkhanova.ksu@mail.ru, ${ }^{3}$ galiya008@mail.ru

Э. Цем

Университет им. Адама Миикевича, Познань, Польиа. E-mail: cemerdemm@gmail.com

\section{Б. Р. Оспанова}

Карагандинский технический университет, Караганда, Казахстан. E-mail: o.b.r@mail.ru

\begin{abstract}
Аннотация. Введение. В Казахстане 55\% будущих учителей английского языка не планируют работать в государственных школах после окончания высшего учебного заведения. В настоящем количественном исследовании, используя статистический анализ, авторы попытались определить причины этого явления.

Цель исследования - определить вероятность раннего выгорания у будущих учителей английского языка с помощью прогностического модемирования.

Методология и методы исследования. Дия создания прогностической модеми авторы использовали следующие инструменты статистического анализа данных: факторный анализ, порядковую регрессию и тест хи-квадрат. Совокупность вышеуказанных инструментов позволяет прогнозировать намерения работать в казахстанской государственной школе более пяти мет. Этот период выступает в качестве косвенной переменной для прогнозирования уровня выгорания будущих учителей. В исследовании приняли участие 160 будущих преподавателей, получивших государственные стипендии на бесплатное обучение с обязательством работать в государственных школах после окончания учебы.

Результаты и научная новизна. Данные показали, что некоторые респонденты будут работать менее пяти мет из-за чувства отчаяния по поводу своей профессии. Результаты показывают, что будущие учителя нуждаются в мучшей подготовке. Кроме того, авторы обнаружили корреляцию между ожиданиями от преподавательской карьеры и гендерным разрывом, когда участники старшего возраста с большей вероятностью намеревались проработать более пяти мет в учебной среде.
\end{abstract}

Образование и наука. Том 23, № 2. 2021 / The Education and Science Journal. Vol. 23, № 2. 2021 
Практическая значимость. Настоящая работа вносит вклад в дальнейшие исследования, направленные на предотвращение нехватки и текучести преподавательского состава на рабочем месте путем выявцения ранних предупреждающих признаков выгорания среди будущих учителей. Определены показатели группы риска начинающих учителей, которые более склонны к выгоранию из-за эмоционального истощения, низких самоэффективности, ожиданий и перспектив педагогической карьеры. По мнению авторов, эффективная профориентация обеспечивает адекватный отбор наиболее мотивированных соискателей с высокими профессиональными ожиданиями.

Ключевые слова: прогностическое моделирование, выгорание студентов, намерение работать, кандидаты в преподаватели английского языка, разочарование на ранней стадии.

для иитирования: Жетписбаева Б. А., Сейлханова А. Е., Саржанова Г. Б., Цем Э., Оспанова Б. Р. Прогностическое моделирование выгорания среди будущих учителей английского языка в Казахстане // Образование и наука. 2021. Т. 23, № 2. С. 71-93. DOI: $10.17853 / 1994-5639-2021-2-71-93$

\section{Introduction}

In modern Kazakhstan, every fifth education graduate has doubts about devoting his or her life to a teaching career. As a recent study shows, 55 per cent of Kazakhstani teacher candidates intend to leave the teaching profession [1]. According to official statistics of Ministry of Education and Science of the Republic of Kazakhstan, in 2017 there was a shortage of 4,580 prospective teachers in Kazakhstan, including 445 English teachers. This indicates that school graduates struggle with career decisions in the teaching profession, and teacher candidates do not plan to work as public school teachers.

Following results, which were based on school principals' reports in the Programme for International Student Assessment (PISA) 2018, showed that the teaching staff shortage and teaching absenteeism resulted in the low performance of student learning [2]. According to the results of the PISA 2018, 15-year-old Kazakh students demonstrated a low proficiency in reading, mathematics, science, and global competence and did not achieve an OECD average level.

Early stage disappointment [3] is a consequence of endless teaching reforms, which sow confusion in the minds of future employees. Moreover, they consider that working as a public school teacher is a less alternative plan when compared to other career choices with higher wages and fewer stresses. Teacher education reform is an indispensable part of the overall educational shifts of the updated curriculum framework in Kazakhstan, which is designed to improve the learning and expertise of teachers. The national plan included a target of training in-service teachers for the following key drivers, 
namely leadership and management in education, assessing for learning and assessment of learning, dialogic teaching and learning, and effective teaching as core segments of quality teaching [4]. According to the strategic directions of the Nazarbayev University Graduate School of Education (2014) [5], Kazakh school teaching staff have been retrained and now, they are engaged in allnew methodological approaches and methods on how to teach in a modern classroom.

Most public school teachers are immersed in the new curriculum, but the situation of higher education is limited. "Meanwhile reform of pre-service teacher education has undergone mainly structural transformations and was rarely prioritised by the government" [6]. The collaboration between the University of Cambridge Faculty of Education, and the Nazarbayev University Graduate School of Education (2015) on the current state of pre-service teacher education in Kazakhstani pedagogical institutions recommends further improvement in the preparation of future teachers. They emphasise the contemporary reform initiatives and meeting requirements of modern teaching practice within a systematic, empirical, and conceptual framework. The recent studies among novice teachers in Kazakhstan [1] have revealed a weak correlation in the preparedness of teacher candidates for the rapid changing shifts in education policy.

\section{Literature Review}

The issue of predicting the early career burnout rates among pre-service teachers in Kazakhstan is not well-researched. Although burnout is wellresearched in the West [7], nothing exists regarding this subject in Kazakhstan. Thus, we consider it is a significant concern to research, as the burnout of inservice teachers can be grounded from premature indicators which are rooted at the undergraduate level. In the nineteen-seventies, psychology researcher Freudenberger (1974) [8] began qualitative research on the physical and emotional symptoms of 'burnout' among medical health workers. Ten years later, social researcher Maslach, and her colleague Jackson (1981) [9], designed measurement indicators of burnout syndrome using three dimensions: emotional exhaustion, depersonalisation, and personal accomplishment. Even today, the Maslach Burnout Inventory (MBI) is recognised as a reliable instrument [10] in assessing the syndrome of exhaustion among humanrelated occupations, including educators. Teachers are an integral part of the school environment, and they often suffer from emotional fatigue and are more susceptible to stress [11]. Some researchers have found evidence of professional burnout among teachers, which is rooted in the period of the undergraduate level. 
According to Fives et al. (2007), "A teacher does not wake up one morning suddenly burned out, rather this is a process that takes place over time, through a multiplicity of causes" [12, p. 918]. Other empirical studies have revealed that student burnout levels are similar to the psychological state of other drained occupational group workers [13, 14]. Other studies addressing the detection of burnout among pre-service teachers are related to student academic achievements $[15,16]$, self-efficacy $[17,18,19]$, occupational anxiety $[20,21]$, and student-teaching practicum stress [11,22].

Our work studied Kazakh pre-service teacher candidates' perceptions about the teaching profession during a contemporary and rapidly-changing education reform. We sought to determine how they represented themselves as teachers, and to know their intentions to work after graduation as public school teachers. We wanted to identify what impacts upon the probability of early career burnout.

\section{Methodology}

\section{Participants}

The population of the research was 160 final year undergraduates enrolled in teacher education departments around Kazakhstan. Female undergraduates accounted for 64.4 per cent of the study population, and males accounted for 30.6 per cent. See Figure 1 below.

All the participants were engaged in actual teaching practicum, in different local public schools, and where they encountered new curriculum shifts. The Kazakh teacher education programme includes four years of study. The applicants, who have received scholarships in the competition for free education at the Government's expense, are obliged to work off their grant by undertaking a minimum of three years' service in public schools after graduation. If they refuse to comply, these graduates must provide full reimbursement to the Government.

\section{Materials and Procedure}

We utilised a quantitative design based on rank scales, which made it possible to build regression models that could be used to predict the behaviour of objects of the research, i. e. the university students.

\section{Reliability Analysis}

From the Maslach Burnout Inventory-Student Survey (MBI-SS) [23], we only made use of the emotional exhaustion dimension. We did not utilise cynicism and academic efficacy (Schaufeli et al., 2002) [14]. Furthermore, emotional exhaustion includes five items. Many Western and non-Western studies utilised this questionnaire, and this fact highlights its internationally recognised 
status (Schaufeli, 2017) [7]. However, there are no records of empirical studies which explore the student burnout rates in the Kazakhstani context. Therefore, the survey was translated from English into Kazakh by three independent Kazakh-speaking PhD in Education and Psychology candidates. The bilingual translators were aware of the guidelines of cross-cultural adaptation [24] in the translation of a questionnaire.

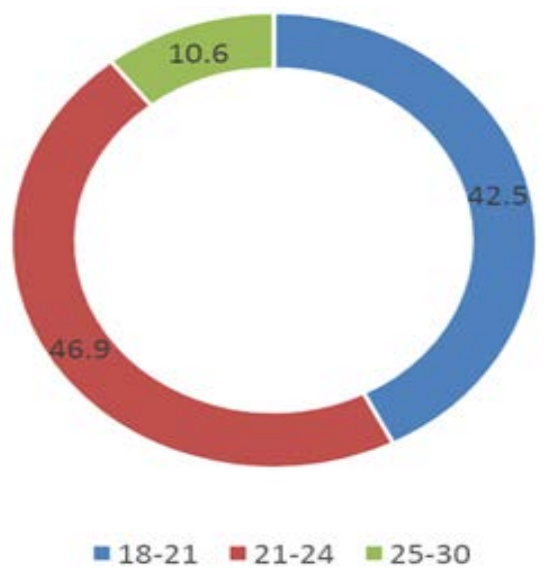

Fig. 1. The demographics of the sample (Age Bracket Categories)

The other 26 questions addressed student attitudes on the desire to work in public schools, preparedness for actual teaching, and current teaching conditions in Kazakhstan. We also gathered data on demographic status to correlate the intention to work in school conditions with age and gender. The questionnaire was designed by the authors. Previously, a pilot survey was conducted to adjust the wording of the statements. Afterwards, the questionnaire was reused. All questions had positive coding aimed at a positive perception of the teaching profession and thus did not require reverse transcoding. The questions in the final questionnaire were tested using a reliability analysis. The results showed the value of the Cronbach's Alpha usability coefficient at a high value of 0.71 , which indicated that there was no need to exclude any question from the questionnaire shown in Table 1.

Table 1

Reliability Statistics of Cronbach's Alpha

\begin{tabular}{|c|c|}
\hline Cronbach's Alpha & N of Items \\
\hline 0.712 & 31 \\
\hline
\end{tabular}




\section{Materials}

Our survey included 31 close-ended questions using a Likert-type scale ranging from 1 or 'strongly agree' to 6 or 'strongly disagree'. The higher scores represented a positive attitude towards being a teacher for the next five years after university graduation. The students were asked a separate question about whether they planned to become teachers, and hypothetically provided them with the freedom to decide based on having no obligations to anyone. The higher the score, the more the participant expressed his or her willingness to work in a public school setting for the next five years. Significantly, this variable acts as a proxy variable that measures and predicts the probability of an early warning sign of burnout in the chosen work. The questionnaire also included several questions to evaluate students' perceptions of being a teacher in rapid changing teaching settings.

\section{Research Hypotheses}

One of the hypotheses of this study is based on rank variables to assess student attitudes to work in public school settings. We can calculate the probability that the students will be exposed to early career burnout and refusal to work as a teacher. Due to a large number of statements, we conducted a factor analysis to reduce the dimension. The values of the factor estimates were stored in the form of four separate variables, i. e. an effective dimensional reduction was achieved. The initial variables, in the amount of 31 pieces, were combined into four factors. These factors were used in an ordinal regression to create a model for predicting the probability of early career burnout. The automated processing of the received data was carried out using the SPSS package.

\section{Findings}

\section{Factor Analysis}

The aim of the first step of the method was to determine the decision making on the optimal number of factors. Moreover, the extracted factors must obey logic and interpretation. Generally, factor extraction stops when the eigenvalues of the newly extracted factors become less than the unity. Each new factor explains the smaller proportion of the initial variance of the original variables. As a result, the built-in algorithm identified nine factors, but only four were found to be significant.

One of the research hypotheses of this study was that several groups of questions are sufficient for the prediction of students' early career burnout. Therefore, setting the number of factors for research purposes was limited to four 
components, with a further verification of their suitability for interpretation. On the graph, which is called a graph of eigenvalues or scree diagram (scree plot), the dots showed are the corresponding eigenvalues of the two coordinates in the space. This type of diagram is usually used in the determination of a sufficient number of factors before rotation. At the same time, it is guided by the following rule: leave only need those factors, which correspond, to the first point on the graph before the curve becomes flatter.

Although the program has identified nine factors, the eigenvalues components which exceeded the unit, the graph shows that after the four factors, the graph becomes flatter. The eigenvalues of the first four factors are greater than two. Thus, four factors are selected reasonably, as shown in Figure 2.

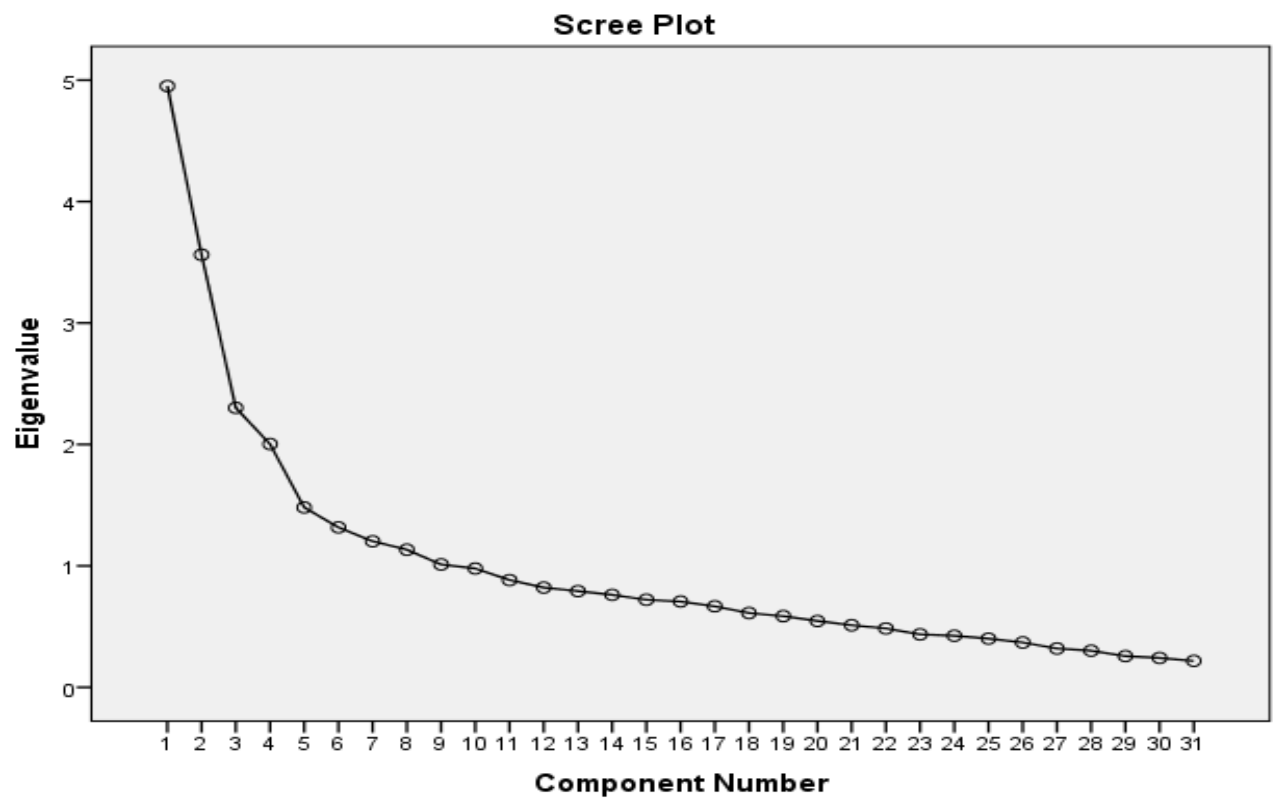

Fig. 2. Graph of eigenvalues

The four components identified by the factor analysis account for 34.59 per cent of the variance. Some factors included only one statement, which indicates the low quality of the identified factors. Furthermore, some components also consisted of only one statement, which does not contribute to the goal of factor analysis, which is to effectively reduce the initial dimension. See Table 2 below. 
Table 2

Explained cumulative variance of nine components

\begin{tabular}{|c|c|c|c|c|c|c|}
\hline \multirow{2}{*}{ 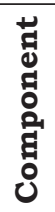 } & \multicolumn{3}{|c|}{ Initial Eigenvalues } & \multicolumn{3}{|c|}{ Rotation Sums of Squared Loadings } \\
\hline & Total & $\begin{array}{c}\text { Variance } \\
\%\end{array}$ & $\begin{array}{c}\text { Cumulative } \\
\%\end{array}$ & Total & $\begin{array}{c}\text { Variance } \\
\%\end{array}$ & $\begin{array}{c}\text { Cumulative } \\
\%\end{array}$ \\
\hline 1 & 4.951 & 15.970 & 15.970 & 3.708 & 11.960 & 11.960 \\
\hline 2 & 3.562 & 11.490 & 27.461 & 2.913 & 9.397 & 21.357 \\
\hline 3 & 2.301 & 7.423 & 34.884 & 2.214 & 7.141 & 28.498 \\
\hline 4 & 2.003 & 6.462 & 41.345 & 1.891 & 6.100 & 34.599 \\
\hline 5 & 1.481 & 4.777 & 46.122 & & & \\
\hline 6 & 1.316 & 4.247 & 50.369 & & & \\
\hline 7 & 1.203 & 3.880 & 54.248 & & & \\
\hline 8 & 1.133 & 3.654 & 57.903 & & & \\
\hline 9 & 1.012 & 3.264 & 61.167 & & & \\
\hline 10 & 0.978 & 3.156 & 64.323 & & & \\
\hline 11 & 0.883 & 2.849 & 67.171 & & & \\
\hline 12 & 0.821 & 2.650 & 69.821 & & & \\
\hline 13 & 0.792 & 2.556 & 72.377 & & & \\
\hline 14 & 0.761 & 2.456 & 74.833 & & & \\
\hline 15 & 0.721 & 2.326 & 77.158 & & & \\
\hline 16 & 0.706 & 2.278 & 79.436 & & & \\
\hline 17 & 0.667 & 2.152 & 81.588 & & & \\
\hline 18 & 0.612 & 1.973 & 83.561 & & & \\
\hline 19 & 0.586 & 1.892 & 85.453 & & & \\
\hline 20 & 0.546 & 1.761 & 87.214 & & & \\
\hline 21 & 0.511 & 1.649 & 88.862 & & & \\
\hline 22 & 0.485 & 1.565 & 90.427 & & & \\
\hline 23 & 0.436 & 1.406 & 91.833 & & & \\
\hline 24 & 0.425 & 1.370 & 93.203 & & & \\
\hline 25 & 0.401 & 1.293 & 94.496 & & & \\
\hline 26 & 0.369 & 1.191 & 95.686 & & & \\
\hline 27 & 0.320 & 1.032 & 96.718 & & & \\
\hline 28 & 0.301 & 0.972 & 97.690 & & & \\
\hline 29 & 0.257 & 0.828 & 98.518 & & & \\
\hline 30 & 0.242 & 0.781 & 99.299 & & & \\
\hline 31 & 0.217 & 0.701 & 100.0 & & & \\
\hline
\end{tabular}

Extraction Method: Principal Component Analysis

The Kaiser-Meyer-Olkin (KMO) value tests sample the adequacy for a factor analysis. The closer it is to the unity, the more the factor analysis can 
highlight clear and reliable factors. Bartlett's sphericity criterion indicates the multidimensional normality of the data. The Bartlett's test showed a statistically significant result $(\mathrm{p}<0.05)$, which indicates the multidimensional normality of the data and that the data are acceptable for factor analysis. The KMO value demonstrates a high value of 0.73 , which shows an acceptable sample adequacy for factor analysis in Table 3 below.

Table 3

KMO and Bartlett's Test results

\begin{tabular}{|l|l|r|}
\hline \multicolumn{2}{|l|}{ KMO and Bartlett's Test } \\
\hline Kaiser-Meyer-Olkin Measure of Sampling Adequacy & 0.730 \\
\hline Bartlett's Test of Sphericity & $\begin{array}{l}\text { Approx. } \\
\text { Chi-Square }\end{array}$ & 1450.162 \\
\cline { 2 - 3 } & df & 465 \\
\cline { 2 - 3 } & Sig. & $1.0268 \mathrm{E}-101$ \\
\hline
\end{tabular}

As a result, the four factors extracting the total percentage of the variance explained by all the factors was 41 per cent. As can be seen from Table 4 below, the percentage of variance explained by the first factor was 13.7 per cent, and the second factor was 13 per cent.

Table 4

Explained cumulative variance of the four components

\begin{tabular}{|l|c|c|c|}
\hline \multirow{2}{*}{ Component } & \multicolumn{3}{|c|}{ Rotation Sums of Squared Loadings } \\
\cline { 2 - 4 } & Total & Variance \% & Cumulative \% \\
\hline Expectations and Perspectives & 4.253 & 13.720 & 13.720 \\
\hline Emotional Exhaustion & 4.051 & 13.068 & 26.789 \\
\hline Self-Efficacy & 2.317 & 7.473 & 34.262 \\
\hline I'm a public school teacher & 2.196 & 7.084 & 41.345 \\
\hline
\end{tabular}

The following Table 5 shows the factor loadings in the component's distribution. The factor load value is smaller than 0.4 and has been hidden as undeserving attention. The factor loads are sorted in a descending order. The first component included all the statements that belong to the grouping of 'expectations and perspectives'. In addition to these statements, another 24 and 28 statements were included, which included "The awareness has come of what needs to be done", and "My attitude to teaching has changed for the better, this is a promising profession". The second component includes statements 
that belong to the grouping of 'emotional exhaustion'. The third factor included three statements out of five, which belong to the grouping of 'self-efficacy'. The last factor included statements related to the grouping of 'I'm a public school teacher'. The statements numbered 22, and 31, were hidden since the value of their factor loads was small. Furthermore, the statement at number 28 entered simultaneously into two factors, the first and fourth, and it entered the fourth factor with a negative sign. In general, we can say that the initial null hypothesis was confirmed, and the statements were distributed among the four factors that can be interpreted fairly and accurately.

Table 5

Explained cumulative variance

\begin{tabular}{|c|c|c|c|c|}
\hline \multirow{2}{*}{} & \multicolumn{5}{|c|}{ Component } & 3 \\
\hline & 1 & 2 & & \\
\hline q1_6 & 0.684 & & & \\
\hline q1_2 & 0.670 & & & \\
\hline q1_7 & 0.631 & & & \\
\hline q1_4 & 0.562 & & & \\
\hline q1_9 & 0.558 & & & \\
\hline q1_3 & 0.551 & & & \\
\hline q1_24 & 0.545 & & & \\
\hline q1_5 & 0.496 & & & \\
\hline q1_8 & 0.492 & & & \\
\hline q1_10 & 0.476 & & & \\
\hline q1_11 & 0.460 & & & \\
\hline q1_28 & 0.450 & & & \\
\hline q1_1 & 0.415 & & & \\
\hline q1_18 & & 0.726 & & \\
\hline q1_13 & & 0.656 & & \\
\hline q1_19 & & 0.654 & & \\
\hline q1_14 & & 0.651 & & \\
\hline q1_12 & & 0.600 & & \\
\hline q1_16 & & 0.600 & & \\
\hline q1_15 & & 0.595 & & \\
\hline q1_20 & & 0.558 & & \\
\hline q1_17 & & & & \\
\hline q1_23 & & & & \\
\hline
\end{tabular}

Образование и наука. Том 23, № 2. 2021 / The Education and Science Journal. Vol. 23, № 2. 2021 


\begin{tabular}{|l|l|l|l|l|}
\hline q1_21 & & & 0.780 & \\
\hline q1_25 & & & 0.447 & \\
\hline q1_31 & & & & \\
\hline q1_27 & & & & 0.635 \\
\hline q1_30 & & & & 0.628 \\
\hline q1_26 & & & & 0.462 \\
\hline q1_29 & & & & 0.421 \\
\hline q1_22 & & & & \\
\hline
\end{tabular}

Figure 3 shows the position of the statements based on the values of the first two factors, which together account for 65 per cent of the variance explained.

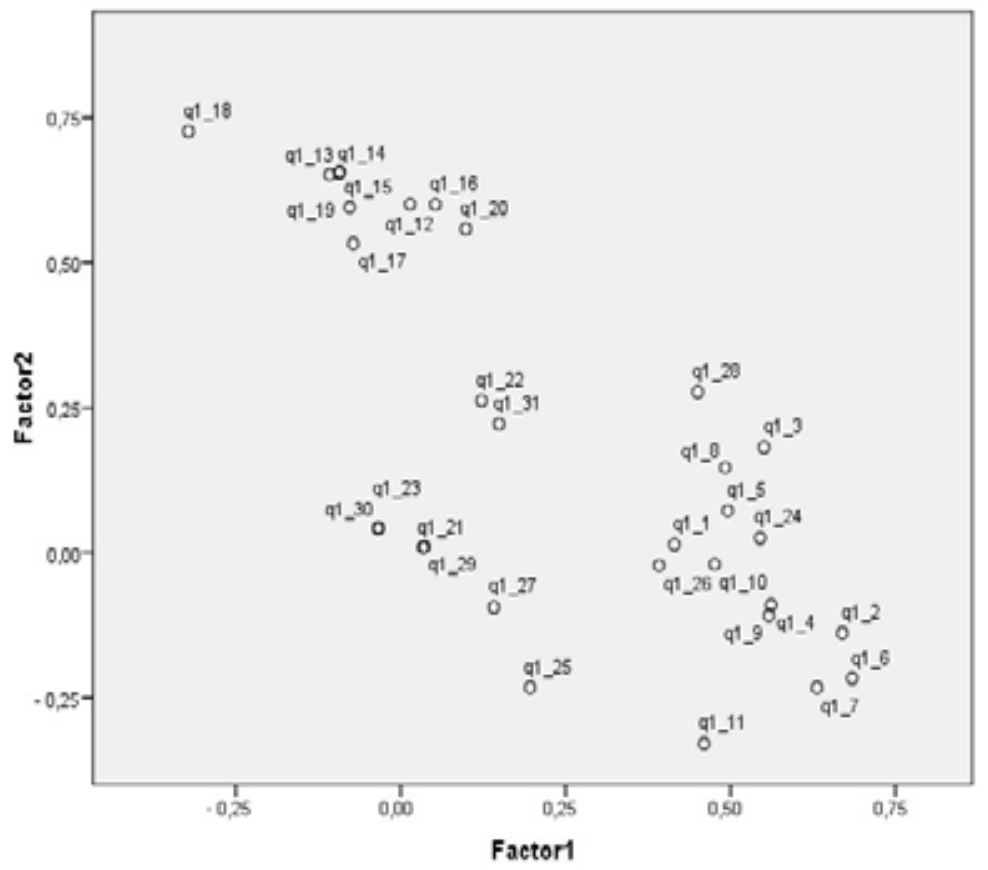

Fig. 3. The location of statements in the two-factor dimension

Figure 3 shows that statements one to 11 , which are related to the first group, 'expectations and perspectives', are grouped in the lower right corner. The statements 12-20, which are related to the second group, 'emotional exhaustion', were grouped in the upper left corner. The statements related to the groupings of 
'self-efficacy' and 'I'm a public school teacher' are somewhat mixed. However, this is normal, as if we could build a four-dimensional graph where the statements related to these groupings would be located separately from each other. As a result of the factor analysis, the values of the factor estimates were stored in the form of four separate variables, i.e. an effective dimensional reduction was achieved. The initial variables, in the amount of 31 pieces, were combined into four factors. Now, these factors will be used in an ordinal regression to create a model for predicting the probability of early career burnout.

\section{Ordinal Regression}

The following method requires constructing a model that predicts the probability of burnout. The dependent variable is the question: "Do you plan to work as a public school teacher in the next five years?". This variable has five gradations, where ' 1 ' means 'no', and ' 5 ' means 'yes' and is an ordinal variable. The independent variables are the factor estimation values of the four components that have been obtained as a result of the factor analysis. An indicator of the quality of the constructed model is measures of certainty: the Pseudo R-Squared of Cox-Snell, Nagelkerke, and McFadden, which are analogues of R2 of linear regression models. This means that the model can explain the proportion of variation of the dependent variable. In this case, the value of the Nagelkerke's $\mathrm{R}$ square is perfect, which indicates the behaviour of the dependent variable by 47.8 per cent, in Table 6.

Table 6

Measures of certainty

\begin{tabular}{|c|c|}
\hline \multicolumn{2}{|c|}{ Pseudo R-Square } \\
\hline Cox and Snell & 0.458 \\
\hline Nagelkerke & 0.478 \\
\hline McFadden & 0.194 \\
\hline Link function: logit & \\
\hline
\end{tabular}

The ordinal regression results in the regression coefficients for the independent variables and categories of the dependent variable. These coefficients were statistically significant in Table 7 . 
Ordinal Regression Coefficients

\begin{tabular}{|c|c|c|c|c|c|c|c|c|}
\hline \multicolumn{9}{|c|}{ Parameter Estimates } \\
\hline & & \multirow{2}{*}{ 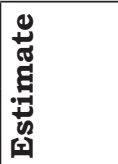 } & \multirow{2}{*}{ 导 䓹 } & \multirow{2}{*}{ స్ } & \multirow{2}{*}{ t) } & \multirow{2}{*}{$\dot{00}$} & \multicolumn{2}{|c|}{$\begin{array}{c}\text { 95\% Confidence } \\
\text { Interval }\end{array}$} \\
\hline & & & & & & & Lower Bound & Upper Bound \\
\hline \multirow{4}{*}{ 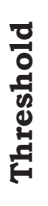 } & {$[\mathrm{q} 2=1.0]$} & -2.810 & 0.296 & 90.055 & 1 & 0.000 & -3.390 & -2.229 \\
\hline & {$[\mathrm{q} 2=2.0]$} & -0.978 & 0.202 & 23.440 & 1 & 0.000 & -1.374 & -0.582 \\
\hline & {$[\mathrm{q} 2=3.0]$} & 0.553 & 0.196 & 7.922 & 1 & 0.005 & 0.168 & 0.938 \\
\hline & {$[\mathrm{q} 2=4.0]$} & 2.502 & 0.290 & 74.438 & 1 & 0.000 & 1.933 & 3.070 \\
\hline \multirow{4}{*}{ 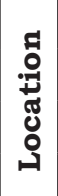 } & FAC1_1 & 1.531 & 0.193 & 62.885 & 1 & 0.000 & 1.153 & 1.910 \\
\hline & FAC2_1 & -0.702 & 0.159 & 19.400 & 1 & 0.000 & -1.014 & -0.389 \\
\hline & FAC3_1 & 0.337 & 0.150 & 5.063 & 1 & 0.024 & 0.043 & 0.630 \\
\hline & FAC4_1 & 0.363 & 0.150 & 5.845 & 1 & 0.016 & 0.069 & 0.657 \\
\hline
\end{tabular}

Link function: logit.

As a result of the calculated coefficients, it is possible to calculate the probability of the occurrence of an event, in this case, the desire to work as a teacher in the future. As an example, we calculate the probability that the first student teacher from the respondents will choose one of five answers.

Table 8

The values of factor loadings for the first student

\begin{tabular}{cccc}
\hline FAC1_1 & FAC2_1 & FAC3_1 & FAC4_1 \\
1.680 & -1.975 & -1.506 & -3.185
\end{tabular}

$$
\begin{aligned}
& p_{1}=\left(\frac{\exp (-2.81-(1.531 * 1.68-0.702 t-1.975+0.337 t-1.506+0.363 t-3.185))}{(1+\exp (-2.81-(1.531 .1 .68-0.702 v-1.975+0.337 v-1.506+0.363 *-3.185)))}\right)=0.006 \\
& p_{2}=\left(\frac{\operatorname{mp}(-0.978-(1.531 * 1.68-0.702 v-1.975+0.337 v-1.506+0.363 v-3.185))}{(1+\operatorname{erp}(-0.978-(1.531 * 1.68-0.702 *-1.975+0.337 v-1.506+0.363 *-3.185)))}\right)-0.006=0.03 \\
& p_{3}=\left(\frac{\exp (-0.553-(1.531 .1 .68-0.702 v-1.975+0.337 v-1.506+0.363 v-3.185))}{(1+\exp (-0.553-(1.531 .1 .68-0.702 v-1.975+0.337 v-1.506+0.363 v-3.185))}\right)-0.006-0.03=0.113 \\
& p_{4}=\left(\frac{\exp (-0.553-(1.531 * 1.68-0.702 v-1.975+0.337 v-1.506+0.363 *-3.185))}{(1+\exp (-0.553-(1.531 .1 .68-0.702 *-1.975+0.337 *-1.506+0.363 *-3.185))}\right)-0.006-0.03-0.113=0.402 \\
& p_{5}=1-p_{1}-p_{2}-p_{3}-p_{4}=1-0.006-0.03-0.113-0.402=0.449
\end{aligned}
$$


Thus, for the first student, the greatest probability is the choice of an answer under the category number five $=0.449$. The predicted and actual significance of the answers coincided with this student, and the model correctly predicted the answer. The SPSS allows automatically calculating these probabilities and the predictive response. Based on the answers to the 31 statements, the algorithm builds a model which observes that when evaluating certain statements, the respondent is more or less likely to choose one of five answers to the question about the desire to be a teacher.

\section{Chi-Square Test}

The relationship between two variables related to the nominal or ordinal scale is analysed using Pearson's Chi-square test, which analyses whether there is a significant difference between the observed and expected frequencies. During the Chi-square test, the mutual independence of two variables in the contingency table is checked, and due to this, the dependence of both variables is indirectly determined. The null hypothesis states that two variables are considered mutually independent if the observed frequencies in the cells coincide with the expected frequencies. If the observed and expected frequencies are statistically different, then the null hypothesis is rejected and an alternative hypothesis is accepted, which claims that the two variables are interdependent.

Table 9 shows the Chi-square test results between the 31 statements and the intention to work as a teacher in public school setting. Seventy-one per cent of the test results showed a positive statistically significant result.

Table 9

Statistical significance of Chi-square test results between dependent and variable statements

\begin{tabular}{|c|c|}
\hline Statement & Asymptotic Significance (two-sided) \\
\hline $\mathrm{q} 1 \_1$ & 1 \\
\hline $\mathrm{q} 1 \_2$ & 1 \\
\hline $\mathrm{q} 1 \_3$ & 0 \\
\hline $\mathrm{q} 1 \_4$ & 1 \\
\hline $\mathrm{q} 1 \_5$ & 1 \\
\hline $\mathrm{q} 1 \_6$ & 1 \\
\hline $\mathrm{q} 1 \_7$ & 1 \\
\hline $\mathrm{q} 1 \_8$ & 1 \\
\hline $\mathrm{q} 1 \_9$ & 1 \\
\hline q1_10 & 1 \\
\hline $\mathrm{q} 1 \_11$ & 1 \\
\hline $\mathrm{q} 1 \_12$ & 1 \\
\hline $\mathrm{q} 1 \_13$ & 1 \\
\hline $\mathrm{q} 1 \_14$ & 1 \\
\hline
\end{tabular}




\begin{tabular}{|c|c|}
\hline q1_15 & 0 \\
\hline q1_16 & 1 \\
\hline q1_17 & 0 \\
\hline q1_18 & 1 \\
\hline q1_19 & 1 \\
\hline q1_20 & 1 \\
\hline q1_21 & 1 \\
\hline q1_22 & 0 \\
\hline q1_23 & 0 \\
\hline q1_24 & 1 \\
\hline q1_25 & 0 \\
\hline q1_26 & 0 \\
\hline q1_27 & 0 \\
\hline q1_28 & 1 \\
\hline q1_29 & 0 \\
\hline q1_30 & 1 \\
\hline q1_31 & 1 \\
\hline Total & 22 \\
\hline Percentage & 0.710 \\
\hline & \\
\hline & \\
\hline & \\
\hline & \\
\hline
\end{tabular}

Table 10 highlights that students' intention to work in public school conditions varies significantly depending on their gender and age. The mature students are more likely to work as a teacher in public schools, with 22 statements or 71 per cent affecting the desire to work as a teacher.

Table 10

Statistical significance Chi-square test results between the dependent variable, and age and sex characteristics

\begin{tabular}{|c|c|}
\hline Relationship & Asymptotic Significance (two-sided) \\
\hline $\mathrm{q} 2{ }^{*} \mathrm{q} 8$ & 1 \\
\hline $\mathrm{q} 2{ }^{*} \mathrm{q} 9$ & 1 \\
\hline
\end{tabular}

\section{Discussion}

One of the top priorities of the intensive Kazakhs policymaking, which is currently underway, is to modernise the education system [25] and retrain inservice school teachers. However, each small teaching reform leaves its mark on future teachers' endurance since they urgently require rapid adaption; flexibility, stress-resistance, expertise, and being highly motivated to work new shifts. Consequently, it may serve as a negative impact on first-year teachers to leave work at the beginning of a career, inasmuch as it is a predictor of burnout. 
An English novice teacher, who has worked for several years in a school setting, can later obtain any wanted jobs, including changing from a teaching career into a higher paying job and in a less stressful environment, due to the high demand of English speaking employees in the job market. Students know what they want after graduation and what perspectives they want to gain. As our study revealed, the respondents who expressed uncertainty or doubt to work for more than five years in public school settings show the early warning signs of burnout, and we forecast that they drop-out of their first workplaces after only a short period.

At the same time, the students were asked to make a decision in a hypothetical situation in which they have no obligations or restrictions, and they are free to choose whether they want to work as teachers or not. This design allows to avoid limitations, real or hypothetical, which are a significant factor for an English teacher, and when deciding whether to work as a teacher in a secondary school. Several of the statements correlated with each other in meanings and were devoted to assessing one common characteristic. For example, assessing the students' expectations and perspectives of a teaching career at an ordinary public school. The factor analysis, as the most interesting option, showed a four-factor solution, which means that 31 initial statements were grouped into four new variables, and losing a fraction of the information during the dimensionality reduction. However, they effectively predicted the occurrence of burnout. Each of the obtained factors was interpreted based upon the statements in which they were included, in one of the four factors.

The first group included statements that concerned students' perceptions of the teaching profession and themselves in this profession, and questions of motivation. This factor was titled, "expectations and perspectives". The second group was combined into a factor called "emotional exhaustion". The third group of questions was made up of statements that evaluated students' beliefs in teaching skills and was referred to as 'self-efficacy'. The fourth group combined statements on the assessment of students' intentions after university graduations.

We used the factor loading for the selection of four components to build a model of the influence of these value groups on the desire to change jobs. The greatest influence on the desire to work in school settings was demonstrated by the first group of questions, which was combined into the 'expectations and perspectives' factor. The higher the student's positive attitude of the teaching profession, the higher his or her willingness to work as a teacher grows. The second factor has a negative relationship with the willingness to work. It can be interpreted as, the higher the emotional burnout, the higher the probability of a desire to change professions or jobs. 
The lack of confidence in teaching skills and motivation among students is perceived as the most important reason causing burnout. Using the developed questionnaire and the model obtained as a result of the regression analysis, it is possible to diagnose, at an early stage, the presence of doubt about the prospects of working as a teacher after graduation. Such a survey can be arranged annually for students of all courses and track the dynamics of the probability of their work on their profile for more than five years. The students with a high degree of this probability need to be paid attention to by grouping them, and familiarising them more deeply with the positive aspects of their work as a teacher. In essence, increasing their motivation to commence a teaching career.

It should also be noted that students are not supposed to take several continuing education courses that can only be attended by teachers who already have teaching experience. This factor is considered by students as a barrier to the development of skills in actual teaching. If possible, it is necessary to make access to continuing education courses as open as possible, especially to online courses. In connection with the results, it is necessary to adjust the process of modernising the training of students who are undergoing study as a prospective English teacher.

\section{Limitations and Recommendations for Future Research}

Therefore, we can propose that the pre-service teacher training should undergo certain changes in order to detect the low-motivated university students as risk groups, and better prepare them for a modern classroom. Discussion is required regarding the need for intervention at the pre-service teacher training in the application of new information technology tools, innovative teaching methods, methods for assessing learning stage, performance, outcomes, and organising their work. Information and communications technology will continue to penetrate the learning process, making work more transparent, and measurable. Kazakhstan is only now taking the first steps in this direction. There are shortcomings in work from both the sides of the innovators, who are the Ministry of Education and Science of the Republic of Kazakhstan, and from the universities. The primary question surrounds when the Kazakhstani education will fully comply with international standards, with its quality and level.

\section{Conclusion}

We achieved the goal of this study, and found that using statistical analysis tools, such as factor analysis, ordinal regression, and chi-square, showed their effectiveness in designing predictive modelling. The factor analysis has 
effectively combined the initial statements into homogeneous and interpretable factors. In turn, the ordinal regression, based on the obtained factors, has shown its high efficiency in predicting the desire of students to work in the teaching profession for a period of five years after graduation. Furthermore, we found a correlation in teaching career expectations and the gender gap, where mature female participants were more likely to carry an intention to work for more than five years. According to our research, we propose the capability to diagnose the phenomenon of teaching staff shortages, which is underpinned by the detection of the early warning signs of burnout among prospective teachers. As noted at the beginning of this article, this will predict a risk group of novice teachers through teaching absenteeism and low motivation. We believe that effective career guidance provides an adequate selection of the most motivated applicants and with high occupational expectations.

\section{References}

1. Irsaliyev S. A ., Kamzoldayev M. B., Tashibayeva D. N., Kopeyeva A. T. Analiticheskij otchet "Uchitelja Kazahstana: pochemu molodye ljudi vybirajut jetu professiju i chto ih motiviruet ostavat'sja v nej?" = Analytical report "Teachers of Kazakhstan: Why young people choose this profession and what motivates them to stay in it ?". Astana: Public Association "Centre for Analysis and Strategy Beles"; 2019. 126 p. (In Russ.)

2. OECD, PISA 2018 Results (Volume II): Where all students can succeed [Internet]. Paris: PISA, OECD Publishing; 2019 [cited 2020 Oct 21]. Available from: https://doi. org/10.1787/b5fd1b8f-en

3. Timoštšuk I., Ugaste A. The role of emotions in student teachers' professional identity. European Journal of Teacher Education. 2012; 35 (4): 421433. DOI: $10.1080 / 02619768.2012 .662637$

4. Kulakhmetova A., McLaughlin C., Ayubayeva N. Preparing teachers: An international review of the evidence on initial teacher education. Research Project "Development of Strategic Directions for Education Reforms in Kazakhstan for 2015-2020". Nazarbayev University Graduate School of Education: Astana; 2014. 35 p.

5. Nazarbayev University Graduate School of Education. Development of Strategic Directions for Education Reforms in Kazakhstan for 2015-2020. Diagnostic report [Internet]. Astana: Indigo print; 2014 [cited 2020 Oct 21]. Available from: https://gse.nu.edu.kz/wp-content/uploads/2018/06/Executive-summary-09feb15.pdf

6. Tastanbekova K. Teacher education reforms in Kazakhstan: Trends and issues. Bulletin of Institute of Education, University of Tsukuba. 2018; 42 (2): 87-97.

7. Schaufeli W. B. Burnout: A short socio-cultural history. In: Neckel S., Schaffner A. K., Wagner G. (eds.). Burnout, fatigue, exhaustion: An interdisciplinary perspective on a modern affliction. Cham: Palgrave Macmillan; 2017. p. 105-127. DOI: https://doi.org/10.1007/9783-319-52887-8_5

8. Freudenberger N. J. Staff burnout. Journal of Social Issues. 1974; 30: 159-165.

9. Maslach C., Jackson S. E. The measurement of experienced burnout. Journal of Occupational Behaviour. 1981; 2 (2): 99-113. 
10. Wheeler D. L., Vassar M., Worley J. A., Barnes L. B. A reliability generalization metaanalysis of coefficient alpha for the Maslach Burnout Inventory. Educational and Psychological Measurement. 2011; 71: 231-244.

11. Kyriacou C. Teacher stress and burnout: an international review. Educational Research. 1987; 29: 146-152.

12. Fives H., Hamman D., Olivarez A. Does burnout begin with student-teaching? Analyzing efficacy, burnout, and support during the student-teaching semester. Teaching and Teacher Education. 2007; 23: 916-934.

13. Pines A., Aronson E., Kafry D. Burnout: From tedium to personal growth. New York: Free Press; 1981. 229 p.

14. Schaufeli W. B., Leiter M. P., Maslach C., Jackson S. E. Maslach Burnout Inventorygeneral survey. In: C. Maslach, Jackson S. E., Leiter M.P. (eds.). The Maslach Burnout Inventory-test manual. $3^{\text {rd }}$ ed. Palo Alto, CA: Consulting Psychologists Press; 1996. p. 19-26.

15. Schaufeli W. B., Martinez M. I., Marques-Pinto A. M., Salanova M., Bakker A. B. Burnout and engagement in university students: A cross-national study. Journal of CrossCultural Psychology. 2002; 33 (5): 464-481.

16. Yang H. J. Factors affecting student burnout and academic achievement in multiple enrollment programs in Taiwan's technical-vocational colleges. International Journal of Educational Development. 2004; 24: 283-301.

17. Bandura A. Self-efficacy: The exercise of control. New York: W.H. Freeman and Company; 1997. 604 p.

18. Skaalvik E. M., Skaalvik S. Teacher self-efficacy and teacher burnout: A study of relations. Teaching and Teacher Education. 2010; 26 (4): 1059-1069.

19. Pendergast D., Garvis S., Keogh J. Pre-service student-teacher self-efficacy beliefs: An insight into the making of teachers. Australian Journal of Teacher Education. 2011; 36 (12): $46-58$.

20. Fuller F. Concerns of teachers: A developmental conceptualization. American Education Research Journal. 1969; 6: 207-226.

21. Klassen R., Wilson E., Siu A., Hannok W., Wong M., Wongsri N., Sonthisap P., Pibulchol C., Buranachaitavee Y., Jansem A. Preservice teachers' work stress, self-efficacy, and occupational commitment in four countries. European Journal of Psychology of Education. 2013; 28 (4): 1289-1309.

22. Mahmoudi F., Özkan Y. Practicum stress and coping strategies of pre-service English language teachers. Procedia-Social and Behavioral Sciences. 2016; 232: 494-501.

23. Maslach C., Jackson S. E., Leiter M. P. Maslach Burnout Inventory Manual (Fourth Edition). Menlo Park, CA: Mind Garden, Inc; 1996-2016. 75 p.

24. Gjersing L., Caplehorn J. R., Clausen T. Cross-cultural adaptation of research instruments: Language, setting, time and statistical considerations. BMC Medical Research Methodology. 2010; 10: 13.

25. Monobayeva A., Howard C. Are post-Soviet republics ready for the new public management? The case of educational modernization in Kazakhstan. International Journal of Public Sector Management. 2015; 28 (2): 150-164 DOI: 10.1108/IJPSM-08-2014-0102

\section{Список использованных источников}

1. Аналитический отчет «Учителя Казахстана: почему молодые мюди выбирают эту профессию и что их мотивирует оставаться в ней?» / С. А. Ирсалиев, М. Б. Камзолда- 
ев, Д. Н. Ташибаева, А. Т. Копеева. Астана: Общественное объединение "Центр анализа и стратегии "Бемес", 2019. 126 с.

2. OECD, PISA 2018 Results (Volume II): Where All Students Can Succeed. Paris: OECD Publishing, 2019. DOI: $10.1787 /$ b5fd1b8f-en

3. Timoštšuk I., Ugaste A. The role of emotions in student teachers' professional identity // European Journal of Teacher Education. 2012. Vol. 35, № 4. P. 421-433. DOI: 10.1080/0 2619768.2012.662637

4. Kulakhmetova A., McLaughlin C., Ayubayeva N. Preparing Teachers: an international review of the evidence on initial teacher education. Research Project "Development of Strategic Directions for Education Reforms in Kazakhstan for 2015-2020". Astana: Nazarbayev University Graduate School of Education, 2014. 35 p.

5. Nazarbayev University Graduate School of Education. Development of Strategic Directions for Education Reforms in Kazakhstan for 2015-2020: Diagnostic report. Astana: Indigo print, 2014. Available from: https:/gse.nu.edu.kz/wp-content/uploads/2018/06/ Executive-summary-09feb15.pdf (date of access: 21.10.2020).

6. Tastanbekova K. Teacher Education Reforms in Kazakhstan: Trends and Issues // Bulletin of Institute of Education, University of Tsukuba. 2018. Vol. 42, № 2. P. 87-97.

7. Schaufeli W. B. Burnout: A short socio-cultural history // S. Neckel, A. K. Schaffner, G. Wagner (eds.). Burnout, fatigue, exhaustion: An interdisciplinary perspective on a modern affliction. Cham: Palgrave Macmillan, 2017. P. 105-127. DOI: 10.1007/978-3-319-52887-8_5

8. Freudenberger N. J. Staff burnout // Journal of Social Issues. 1974. № 30. P. 159-165.

9. Maslach C., Jackson S. E. The measurement of experienced burnout // Journal of Occupational Behaviour. 1981. Vol. 2, № 2. P. 99-113.

10. Wheeler D. L., Vassar M., Worley J. A., Barnes L. B. A reliability generalization metaanalysis of coefficient alpha for the Maslach Burnout Inventory // Educational and Psychological Measurement. 2011. № 71. P. 231-244.

11. Kyriacou C. Teacher stress and burnout: an international review // Educational Research. 1987. № 29. P. 146-152.

12. Fives H., Hamman D., Olivarez A. Does burnout begin with student-teaching? Analyzing efficacy, burnout, and support during the student-teaching semester // Teaching and Teacher Education. 2007. № 23. P. 916-934.

13. Pines A., Aronson E., Kafry D. Burnout: From Tedium to Personal Growth. New York: Free Press, 1981. 229 p.

14. Schaufeli W. B., Leiter M. P., Maslach C., Jackson S. E. Maslach Burnout Inventorygeneral survey // C. Maslach, S. E. Jackson, M. P. Leiter (eds.). The Maslach Burnout Inventorytest manual. 3rd ed. Palo Alto, C. A.: Consulting Psychologists Press, 1996. P. 19-26.

15. Schaufeli W. B., Martinez M. I., Marques-Pinto A. M., Salanova M., Bakker A. B. Burnout and engagement in university students: a cross-national study // Journal of CrossCultural Psychology. 2002. Vol. 33, № 5. P. 464-481.

16. Yang H. J. Factors affecting student burnout and academic achievement in multiple enrollment programs in Taiwan's technical-vocational colleges // International Journal of Educational Development. 2004. № 24. P. 283-301.

17. Bandura A. Self-efficacy: The exercise of control. New York: W. H. F., 1997. 604 p.

18. Skaalvik E. M., Skaalvik S. Teacher self-efficacy and teacher burnout: A study of relations // Teaching and Teacher Education. 2010. Vol. 26, № 4. P. 1059-1069. 
19. Pendergast D., Garvis S., Keogh J. Pre-Service Student-Teacher Self-efficacy Beliefs: An Insight Into the Making of Teachers // Australian Journal of Teacher Education. 2011. Vol. 36, № 12. P. 46-58.

20. Fuller F. Concerns of teachers: A developmental conceptualization // American Education Research Journal. 1969. № 6. P. 207-226.

21. Klassen R., Wilson E., Siu A., Hannok W., Wong M., Wongsri N., Sonthisap P., Pibulchol C., Buranachaitavee Y., Jansem A. Preservice teachers' work stress, self-efficacy, and occupational commitment in four countries // European Journal of Psychology of Education. 2013. Vol. 28, № 4. P. 1289-1309.

22. Mahmoudi F., Özkan Y. Practicum Stress and Coping Strategies of Pre-service English Language Teachers // Procedia-Social and Behavioral Sciences. 2016. № 232. P. 494-501.

23. Maslach C., Jackson S. E., Leiter M. P. Maslach Burnout Inventory Manual (Fourth Edition). Menlo Park, C. A.: Mind Garden, Inc. 1996-2016. 75 p.

24. Gjersing L., Caplehorn J. R., Clausen T. Cross-cultural adaptation of research instruments: language, setting, time and statistical considerations // BMC Medical Research Methodology. 2010. № 10. P. 13.

25. Monobayeva A., Cosmo Howard. Are post-Soviet republics ready for the new public management? The case of educational modernization in Kazakhstan // International Journal of Public Sector Management. 2015. Vol. 28, Iss. 2. P. 150-164. DOI: 10.1108/ IJPSM-08-2014-0102

\section{Information about the authors:}

Bakhytgul A. Zhetpisbayeva - Dr. Sci. (Education), Professor, Vice-Rector for Strategic Development, Buketov Karaganda University; ORCID 0000-0002-1528-4494; Karaganda, Kazakhstan. E-mail: zhetpisbajeva@mail.ru

Ainur Ye. Seilkhanova - PhD Student, Department of the Theory and Practice of Foreign Language Training, Faculty of Foreign Languages, Buketov Karaganda University; ORCID 0000-0002-9087-868X; Karaganda, Kazakhstan. E-mail: seylkhanova.ksu@mail.ru

Galiya B. Sarzhanova - PhD (Philosophy), Head of the Department of Theory and Practice of Foreign Language Training, Faculty of Foreign Languages, Buketov Karaganda University; ORCID 0000-0002-3461-8963; Karaganda, Kazakhstan. E-mail: galiya008@mail.ru

Erdem Cem - Professor, Department of Asian Studies, Adam Mickiewicz University; ORCID 0000-0002-1482-7901; Poznan, Poland. E-mail: cemerdemm@gmail.com

Bikesh R. Ospanova - Cand. Sci. (Philology), Head of the Department of Russian Language and Culture, Karaganda Technical University; ORCID 0000-0001-8070-2181; Karaganda, Kazakhstan. E-mail: o.b.r@mail.ru

Contribution of the authors. The authors equally contributed to the present research.

Conflict of interest statement. The authors declare that there is no conflict of interest.

Received 17.10.2020; accepted for publication 13.01.2021.

The authors have read and approved the final manuscript. 


\section{информаиия об авторах:}

Жетписбаева Бахытгумь Асымбековна - доктор педагогических наук, професcop, проректор по стратегическому развитию Карагандинского университета им. Е. А. Букетова; ORCID 0000-0002-1528-4494; Караганда, Казахстан. E-mail: zhetpisbajeva@mail.ru

Сеймханова Айнур Ергапиевна - докторант Кафедры теории и методики иноязычной подготовки факультета иностранных языков Карагандинского университета им. E. А. Букетова; ORCID 0000-0002-9087-868X; Караганда, Казахстан. E-mail: seylkhanova. ksu@mail.ru

Саржанова Гамия Байжумаевна - PhD (философия), заведующая кафедрой теории и методики иноязычной подготовки факультета иностранных языков Карагандинского университета им. Е. А. Букетова; ORCID 0000-0002-3461-8963; Караганда, Казахстан. E-mail: galiya008@mail.ru

Цем Эрдем - профессор департамента азиатских исследований Университета им. Адама Мицкевича; ORCID 0000-0002-1482-7901; Познань, Польша. E-mail: cemerdemm@ gmail.com

Оспанова Бикеш Ревовна - кандидат филологических наук, заведующая кафедрой русского языка и культуры Карагандинского технического университета; ORCID 0000-0001-8070-2181; Караганда, Казахстан. E-mail: o.b.r@mail.ru

Вклад соавторов. Авторы внесли равный вклад в подготовку статьи.

информация о конфликте интересов. Авторы заявляют об отсутствии конфмикта интересов.

Статья поступима в редакцию 17.10.2020; принята в печать 13.01.2021.

Авторы прочитали и одобрили окончательный вариант рукописи. 